\title{
The Neutrophil's Choice: Phagocytose vs Make Neutrophil Extracellular Traps
}

\author{
Angelo A. Manfredi ${ }^{1,2 *}$, Giuseppe A. Ramirez ${ }^{1,2}$, Patrizia Rovere-Querini ${ }^{1,2}$ \\ and Norma Maugeri ${ }^{1,2}$
}

${ }^{1}$ Università Vita-Salute San Raffaele, Milano, Italy, ${ }^{2}$ Division of Immunology, Transplantation and Infectious Diseases, IRCCS Ospedale San Raffaele, Milano, Italy

Neutrophils recognize particulate substrates of microbial or endogenous origin and react by sequestering the cargo via phagocytosis or by releasing neutrophil extracellular traps (NETs) outside the cell, thus modifying and alerting the environment and bystander leukocytes. The signals that determine the choice between phagocytosis and the generation of NETs are still poorly characterized. Neutrophils that had phagocytosed bulky particulate substrates, such as apoptotic cells and activated platelets, appear to be "poised" in an unresponsive state. Environmental conditions, the metabolic, adhesive and activation state of the phagocyte, and the size of and signals associated with the tethered phagocytic cargo influence the choice of the neutrophils, prompting either phagocytic clearance or the generation of NETs. The choice is dichotomic and apparently irreversible. Defects in phagocytosis may foster the intravascular generation of NETs, thus promoting vascular inflammation and morbidities associated with diseases characterized by defective phagocytic clearance, such as systemic lupus erythematosus. There is a strong potential for novel treatments based on new knowledge of the events determining the inflammatory and pro-thrombotic function of inflammatory leukocytes.

Keywords: neutrophils, apoptosis, phagocytosis, NETs, platelets

${ }^{*}$ Correspondence:

Angelo A. Manfredi manfredi.angelo@hsr.it

Specialty section: This article was submitted to

Molecular Innate Immunity, a section of the journal

Frontiers in Immunology

Received: 24 October 2017 Accepted: 01 February 2018 Published: 20 February 2018

Citation:

Manfredi AA, Ramirez GA, Rovere-Querini $P$ and Maugeri N (2018) The Neutrophil's Choice: Phagocytose vs Make Neutrophil Extracellular Traps.

Front. Immunol. 9:288. doi: 10.3389/fimmu.2018.00288

\section{NEUTROPHILS RECOGNIZING PARTICULATE SUBSTRATES}

Neutrophils activate stereotyped programs when the environment changes. As most professional phagocytes, they react when challenged with bulky preys. Neutrophils kill microbes via phagocytosis, generation of oxidant species, and activation of the cell proteolytic machinery, processes that have been extensively studied in the last decades. The release of neutrophil extracellular traps (NETs) vicariates frustrated or ineffective phagocytosis. It enhances the efficacy of the innate response coping with invading microbes. Moreover, NETs counterbalance microbial strategies to evade the immune response. NETs are large macromolecular structures that comprise neutrophil DNA, citrullinated histones, and an array of active proteases $(1,2)$. Because of the adhesive properties of nucleic acids and of the action in the extracellular environment of histones and of neutrophil enzymes, NETs contribute to the host defense against various microbial species (3). They form a three-dimensional template absorbing and retaining players of the humoral innate immune response, the prototypic long pentraxin, pentraxin 3 , and complement (4-8).

Excellent recent reviews detail the mechanisms involved in the generation of NETs and we remand to them interested readers $(3,9-13)$. Of importance, NET formation and extrusion implies 
a dramatic rearrangement of the neutrophil intracellular architecture. Chromatin decondensation is a prerequisite for NET assembly and depends on the citrullination of histones driven by the PAD4 enzyme $(14,15)$, by the action of DEK, a nuclear chromatin protein involved in epigenetic and transcriptional regulation (16), and by the concerted action of enzymes, which are partially complexed in the azurophilic primary granules, myeloperoxidase, and elastase. Elastase action is responsible of the partial proteolytic processing necessary to disrupt chromatin packaging (17-19). von Willebrand factor adsorbed to NETs, citrullinated histones, and nucleic acid negative charges concur to the recruitment and the activation of platelets, thus impacting on hemostasis and eventually favoring thrombosis. Thrombosis initiated by the innate immunity, also referred to as "immunothrombosis," plays an increasingly recognized role in vessel protection, limiting the intravascular growth and the hematogenic spread of infectious agents $(5,20-23)$. Conversely, endogenous mechanisms involving DNase1 and DNase1-like 3 control the thrombogenic potential of NETs in vivo, under conditions where microbial and sterile stimuli are responsible for the activation of neutrophils (24).

In this essay, we focus on neutrophils that face non-microbial "unconventional" particulate substrates, apoptotic cells, and activated platelets in particular. Non-infectious particulates do not usually pose a direct challenge to the integrity of the organism. However, they cause neutrophil responses surprisingly similar to those caused by microbes, including most notably phagocytosis and generation of NETs. Neutrophils avidly phagocytose apoptotic cells and are the prominent scavengers of cell remnants in biological fluids, the blood in particular, where they represent the counterpart of scavenger macrophages in solid tissues. Neutrophils that had internalized extracellular nuclei are referred to as "LE cells," and they represent a virtually unique feature of the prototypical systemic autoimmune disease, systemic lupus erythematosus $(\operatorname{SLE})(25,26)$. Initially, the LE phenomenon was thought to reflect the lysis of a neutrophil lobe. In contrast, the intracellular vesicles contain entire nuclei that had actually been phagocytosed, transferred into the phagolysomes, and partially digested. Phagocytosis has been confirmed by flow cytometry $(27,28)$ and depends on factors in the biological fluids of patients with SLE, in particular autoantibodies recognizing nuclear antigens, histones and DNA, and complement (25). LE cells have been originally identified in the bone marrow of lupus patients. They have been found in the blood, synovial and cerebrospinal liquids, and serosal effusion $(25,26)$. The LE phenomenon can be induced in vitro and, besides highlighting the importance of opsonizing signals, reveals that whole nuclei are frequently present in biological fluids. This might depend on pyroptosis, an inflammatory form of cell death, in which entire nuclei surrounded by the nuclear membrane are released together with inflammatory cytokines in the microenvironment (29).

Indeed cytokines and other signals important in phagocyte biology, including the growth factor, GM-CSF, are known to enhance the ability of neutrophils in the fluid phase to recognize and to internalize apoptotic cells (30-32). Conversely, the depletion of phagocytes before sterile acute tissue injuries causes the accumulation of cell debris, influencing the outcome of the repair and the associated immune response $(33,34)$. Thus, neutrophils emerge as key players in the maintenance of tissue homeostasis in physiological conditions (35).

Neutrophils and platelets frequently and extensively interact in the peripheral blood and at sites of inflammation. Their cross-talk is important in the maintenance of the homeostasis. Platelets scan the vascular surface and collect deposited bacteria, boosting neutrophil activities such as NET generation (36), while the deregulated neutrophil-platelets interaction plays a role in the pathogenesis of rheumatic diseases $(21,37,38)$ and severe sepsis (39). Platelets and neutrophils adhere and form heterotypic aggregates, which are found not only in the blood of patients with inflammatory or autoimmune diseases but also in the blood of patients with cancer and acute coronary syndromes (40). Heterotypic aggregates sustain and amplify the activation of platelets and neutrophils, fostering their inflammatory, antibacterial, hemostatic, and pro-thrombotic actions (11). The ability to release cytokines, chemokines, and vasoactive molecules and the enhanced ability of leukocytes to extravasate and to reach inflamed tissues reflect the reciprocal activation of platelets and neutrophils $(36,41-44)$.

Neutrophil-platelet initial interaction depends in vitro and in vivo on platelet P-selectin interaction with the PSGL1 receptor on leukocytes (45-49). Because of the initial tethering event, neutrophils redistribute their vesicular content and expose on the plasma membrane biologically active molecules, such as myeloperoxidase and tissue factor, which are normally contained in the granules or in the cytoplasm. Moreover, they upregulate the expression of phagocyte $\beta 2$ integrins that are transactivated, acquiring a higher affinity for the fibrinogen presented by platelet $\alpha$ integrins. The latter interaction stabilizes the adhesion between the phagocyte and the platelet (50-52) (Table 1).

Depending on environmental conditions, the phagocyte metabolism, activation and interaction with the extracellular matrix, and still poorly identified signals expressed/released by the tethered platelets, three outcomes can be envisaged. First, at the end of the sustained interaction, leukocytes dissociate from platelets-possibly because of active proteolysis of ligands by neutrophil enzymes - and reach the inflammatory sites where they exert their effector function (41-43, 55, 67).

Second, active engulfment takes place, which is exquisitely dependent on the recognition of a common feature of activated platelets, i.e., the exposure of anionic phospholipids, such as phosphatidylserine (PS). The direct or indirect recognition of PS on the prey can result in the rearrangement of actin-based cytoskeleton and the internalization of the tethered platelet by professional and non-professional phagocytes, such as endothelial cells $(51,55,68,69)$. Under physiological conditions, recognition and phagocytic clearance of activated platelets purge the bloodstream of procoagulant stimuli while quenching the neutrophil sensitivity to inflammatory stimuli (see below) (70). The phagocytic removal of activated platelets conforms to the "tether and tickle" model originally proposed for the removal of apoptotic dying cells by Fadok, Henson, and collaborators (71, 72). This is a two-step model in which (i) the dying cell is initially tethered to the phagocyte and (ii) other interactions based 
TABLE 1 | Some defined platelet/neutrophil molecular interactions.

\begin{tabular}{|c|c|c|c|c|}
\hline $\begin{array}{l}\text { Platelet/ } \\
\text { platelet-derived } \\
\text { microparticles }\end{array}$ & Bridging moiety & Neutrophil & Possible outcome & $\begin{array}{l}\text { Main relevant } \\
\text { references }\end{array}$ \\
\hline \multirow[t]{3}{*}{ P-selectin } & None described & PSGL1 & Neutrophil $\beta 2$ integrin upregulation/transactivation & $(50,53,54)$ \\
\hline & & & Neutrophil degranulation & $(51,55-57)$ \\
\hline & & & ROS generation & $(58,59)$ \\
\hline \multirow[t]{3}{*}{ PS } & Gas-6? & MERTK? & Platelets clearance via phagocytosis & $(51)$ \\
\hline & Protein S? & $A X L ?$ & & \\
\hline & $\begin{array}{l}\text { MFG-8 } \\
\text { Others? }\end{array}$ & RAGE? & Phagocyte hyporesponsiveness to further inflammatory stimuli & $(51)$ \\
\hline \multirow[t]{6}{*}{ HMGB1 } & None described & RAGE & Neutrophil $\beta 2$ integrin upregulation/transactivation & $(58,60,61)$ \\
\hline & & & Pericellular distribution of myeloperoxidase and elastase from primary granules & $(58,60,61)$ \\
\hline & & & Mitochondrial ROS formation & $(23,62,63)$ \\
\hline & & & Autophagy & $(58,61)$ \\
\hline & & & Inflammatory-mediated tissue damage & $(60,64,65)$ \\
\hline & & & NETs generation and thrombosis & $(58,65)$ \\
\hline Glycoprotein lb & & Activated Mac-1 & Adhesion of resting platelets to activated neutrophils & $(63)$ \\
\hline$\alpha \| \beta 3$ & Fibrinogen & Activated Mac-1 & Adhesion of resting platelets to activated neutrophils & $(66)$ \\
\hline
\end{tabular}

MFG-E8, milk fat globule-EGF factor 8; NET, neutrophil extracellular trap; ROS, reactive oxygen species.

on the direct or indirect recognition of PS transduce signals that initiate cell internalization $(73,74)$. In the case of activated platelets, the initial tethering depends on P-selectin recognition and immediately downstream events, while the availability of PS appears crucial for actual internalization of the phagocytic substrate $(51,55,68,69)$.

Third, the firm interaction between neutrophils and tethered PS-expressing phagocytic substrates is a potent inducer of NETs (see below). Indeed, regulation of the overall charge of the phagocytic substrate, like it occurs during apoptosis when glycosylated epitopes undergo caspase-dependent desialylation, influences the interaction between phagocyte and prey and the efficacy of the clearance (75).

\section{PS AND CELL CLEARANCE PROGRAMS}

Phospholipid translocases, scramblases, and flippases, maintain the asymmetry of the plasma membrane phospholipids. Upon platelet activation triggered by various agonists, the intracellular $\mathrm{Ca}^{2+}$ concentration sharply increases, interfering with the translocase action and causing the rapid, patchy, potentially transient exposure of PS (76). The pathway involves the disruption of the platelet inner mitochondrial membrane, an event underlying PS exposure by activated, apoptotic and senescent platelets (77). Activated cells often expose PS without being phagocytosed. This points out to the existence of "do not eat me" signals. The dynamics of exposure of PS represents another variable (78). PS recognition leads to phagocytosis only when PS aggregation by tethering receptors causes firm and lasting interactions between the phagocyte and the prey. Such tethering receptors comprise Tim4 for apoptotic cells and possibly PSGL1 for activated platelets $(78,79)$. Finally, cells dying because of caspase-mediated programmed cell death might expose modified PS residues, thus providing a better substrate for recognition from at least some PS receptors (see below) and tagging cells for phagocytic clearance $(80,81)$.

In support, hindrance with the recognition of oxidized lipids interferes with the interaction between phagocyte and prey and the ensuing clearance of apoptotic cells (82). Moreover internalized oxidized phospholipids and oxysterols cause the activation of PPAR-delta receptors (83) and the LXR nuclear receptor in macrophages (84) in turn inducing the expression in macrophages of signals that further enhance the process such as the Mer receptor (84).

Oxidation-specific epitopes in general are recognized by various pattern recognition receptors and components of the humoral innate immune systems, tagging for removal damaged cells and low-density lipoproteins. Of interest, natural IgM antibodies specifically and effectively bind to oxidized epitopes on blood microparticles, quenching their ability to trigger the production of inflammatory signals, IL-8 in particular from macrophages (85). Conversely, the accumulation of oxidized moieties per se cause unrelenting inflammation and contribute to various human vascular disease, including atherosclerosis (85-87).

Diverse receptors recognize PS, either directly or through the moieties that PS binds on the outer leaflet of the plasma membrane. Receptors include Tim4, the tyrosine kinase receptors Tyro3, Axl, and Mer (78, 88, 89). "Bridging" molecules comprise structurally and functionally heterogeneous soluble ligands such as Protein S, Gas-6, and milk fat globule-EGF factor 8 (MFG-E8). Microparticles released from activated platelets bind via PS to Protein S and Gas-6 (90). Gas-6 stabilizes the interaction among activated platelets, endothelial cells, and leukocytes facilitating heterotypic cell aggregation in the blood (91), while the interaction among PS, GAS-6, and the Axl receptor mediates microparticle clearance (90). MFG-E8 has been as well implicated in the formation of heterotypic aggregated and in PS-mediated clearance of platelets in in vivo models of sepsis 
(69). Human neutrophils constitutively express the Mer receptor and upregulate its expression in septic conditions (92) (Table 1). Other molecules related to the humoral innate immune responses such as the beta2-glycoprotein 1, pentraxins, and complement fractions bind to apoptotic cells and activated platelets influencing their immunogenicity either because they provide a template for autoantibody binding or because they facilitate the local generation of adjuvant signals (8, 93-100).

Direct or indirect PS recognition is required on the one hand for the efficacy of phagocytosis. It also causes the selective production of cytokines such as IL-10 and TGF- $\beta$ and specialized classes of pro-resolving lipidic mediators such as resolvins (101-106) that prompt the active termination of the inflammatory response. In concert with the cytokines, IL-4 and IL-13, PS recognition links tissue damage to tissue repair by the reprogramming of local macrophages (107), which in turn guide the activation, the proliferation, and the survival of stem and progenitor cells (108-111).

Tampering with the recognition of PS or PS-associated moieties thus leads to the accumulation of apoptotic debris, to persisting unrelenting inflammation, and to the failure in the ability of injured or damaged tissues to heal. Moreover, it is closely associated with the development of autoimmunity, often with serological and clinical features of the prototypic systemic autoimmune disease, SLE $(86,112-116)$. Autoimmunity follows the cross-presentation of apoptotic cell antigens to autoreactive $\mathrm{T}$ cells in genetically susceptible backgrounds $(114,117-125)$. Autoimmunity, unrelenting inflammation, and accumulation of cell remnants associate in human SLE and in most SLE experimental models with alteration of blood neutrophils (126). Exogenous MFG-E8 corrected in vivo most alterations (see above), highlighting the link of systemic autoimmunity, defective neutrophil function, and the recognition of PS (127).

\section{WHEN THE GAME IS TOUGH, NEUTROPHILS LOOK FOR COMPANY}

As discussed above, the interaction with particulate substrates can trigger the production of NETs (128). The seminal work of Clark and collaborators has revealed that in experimental models of sepsis, bacterial LPS primarily activate the TLR4 of platelets. In turn, TLR4-activated platelets interact with neutrophils and commit them to the generation of NETs NETs $(39,129)$. Besides microbial constituents, sterile stimuli leading to platelet activation cause the generation of signals that trigger neutrophil activation and favor the production of NETs (58). HMGB1 is a prototypic endogenous inflammatory signal, which is expressed by platelets, is released upon activation, and represents a master regulator of leukocyte inflammatory activation and thromboinflammation (60-62, 130-135). Indeed the presentation of bioactive HMGB1 - either soluble or associated with the plasma membrane of tethered platelets or of platelet-derived microparticles (58, 60-62, 64, 65, 130) - to neutrophils represents a non-redundant signal, by which platelets instruct neutrophils to release NETs, via a pathway that involves the HMGB1 receptor expressed by neutrophils, RAGE (13). Platelets represent a "barometer" used by neutrophils to decide whether they should undergo activation.
NETs generation occurs when inflammatory stimuli of microbial or endogenous origin exceed a threshold acceptable for platelets only $(11,39,49)$.

\section{NEUTROPHILS THAT HAVE PHAGOCYTOSED KEEP CALM}

The platelet barometer works not only by soliciting neutrophil responses but also by switching them off. Neutrophils that had phagocytosed bulky particulate substrates, such as apoptotic cells and activated platelets, appear to be "poised" in an unresponsive state, since they become unable to respond to further inflammatory stimuli and fail to release their granular content or to generate NETs $(51,68,128,136)$. The "calming touch" associated with the phagocytosis of large PS-exposing particulate substrate (137) (Figure 1) might limit the collateral damages to inflamed vessels and tissues by the unrestrained activation of neutrophils (138).

\section{THE CHOICE OF NEUTROPHILS IN FRONT OF CRYSTALS AND MICROPARTICLES}

Monosodium urate crystals, whose precipitation is the key event in the pathogenesis of gout (139), are potent NET inducers. Recent elegant studies have shed light on the clinical pattern of early gouty arthritis. This stage of the disease is characterized by acute and transient inflammatory responses to crystals that cannot be eliminated through phagocytosis and persist in the tissues of patients for long periods (140). Early phases after crystal precipitation are characterized by the production of inflammatory cytokines, IL- 8 and IL- $1 \beta$ in particular $(139,141)$, and by the noxious effects of isolated, pro-inflammatory NETs (142). Later neutrophils accumulate within the tissue. The concentration of locally produced NETs increases, favoring NET aggregation. Aggregated NETs provide a proteolytic template, which traps cytokines and chemokines that undergo degradation by the neutrophil proteases associated with the NET DNA backbone. Inactivation of the chemokines and cytokines leads the swift termination of the inflammatory response despite persistence of precipitated crystals $(140,143)$, while aggregated NETs contribute to tissue damage and remodeling in late phases of the disease, referred to as tophaceous gout (142).

Environmental signals and intracellular events shape the transient response elicited by the crystals. They include (i) still uncharacterized signals activating the P2Y6 purinergic receptor/store-operated calcium entry/IL-8 axis (144) and (ii) the presence of IL-1 $\beta$, combined with the ability of neutrophils to activate the autophagic machinery (145). IL-1 $\beta$ and autophagydependent NET generation also play a critical role in Familial Mediterranean fever, possibly the best characterized autoinflammatory disease, whose clinical manifestations comprise transient self-limiting inflammatory phases with fever, polyserositis, and acute phase responses (146). Neutrophil ability to activate autophagy is selectively downregulated during remitting phases of Familial Mediterranean fever via upregulation of the stressrelated protein REDD1 (regulated in development and DNA 

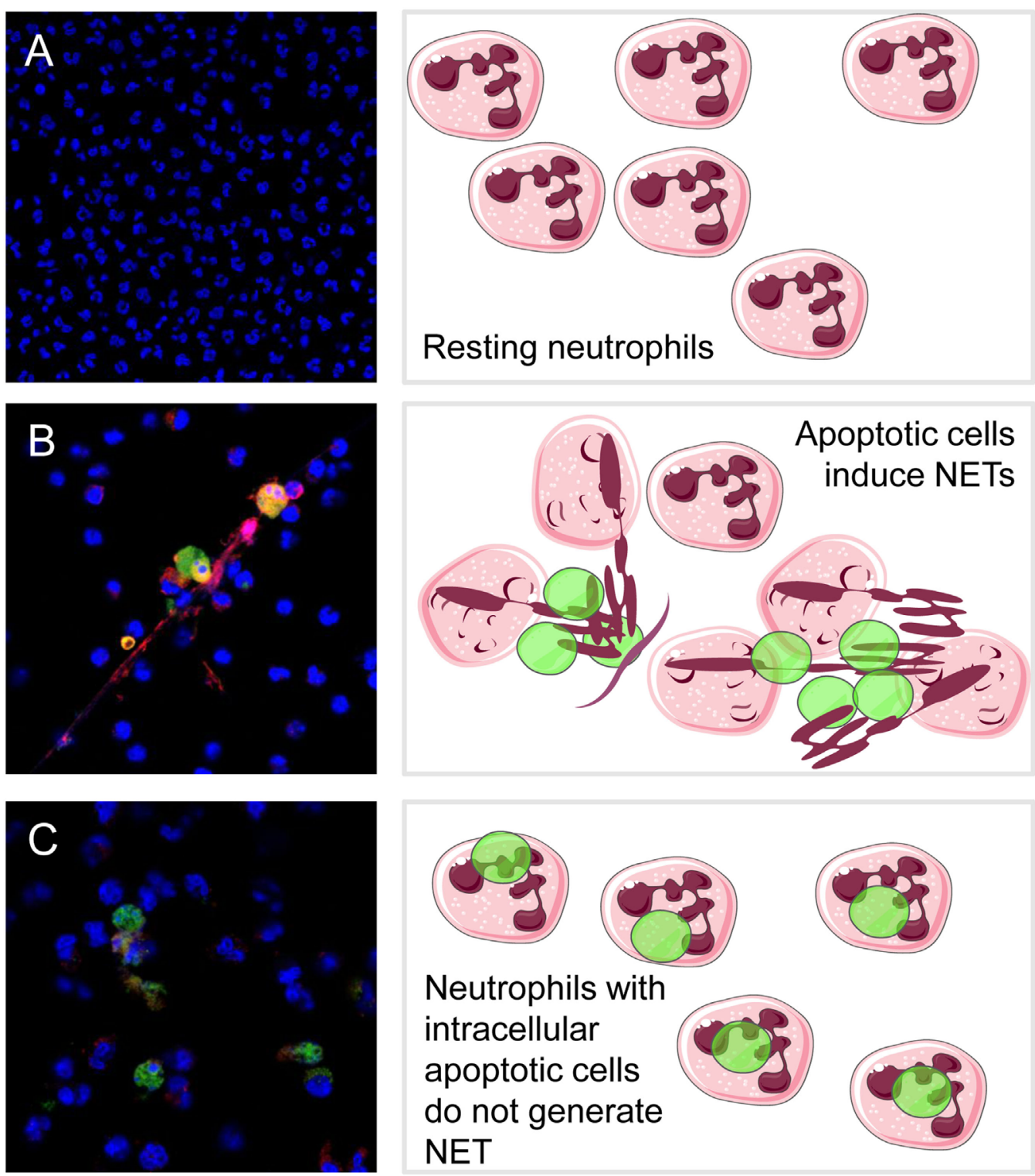

Neutrophils with intracellular apoptotic cells do not generate NET
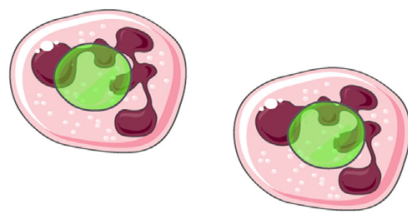

D

stimuli

Activated Neutrophils

Neutrophils with adherent tethered $\mathrm{PS}^{+}$cargos

Neutrophils with intracellular $\mathrm{PS}^{+}$cargos + stimuli

\section{B2 integrin up-regulation}

\begin{tabular}{cc}
$\begin{array}{c}\text { Activated platelet } \\
\text { fMLP }\end{array}$ & $\begin{array}{c}\text { Apoptotic cell } \\
\text { IL-8 }\end{array}$ \\
\hline 100 & 100 \\
$242.8 \pm 31.2$ & $136.0 \pm 38.2$ \\
$158.6 \pm 25.8$ & $102.1 \pm 28.7$ \\
$126.5 \pm 12.1$ & $106.0 \pm 24.1$
\end{tabular}

FIGURE 1 | Neutrophils that had phagocytosed apoptotic cells or activated platelets fail to be activated when challenged with further inflammatory stimuli. Neutrophil extracellular traps (NETs) formation was monitored by confocal microscopy. Cathepsin G was revealed by immunofluorescence (Alexa Fluor 541, red), and DNA was counterstained with Hoechst and apoptotic cells preloaded with CFSE (equivalent to Alexa 488, green). (A) Unstimulated neutrophils; (B) neutrophils challenged with apoptotic cells; (C) neutrophils that had phagocytosed apoptotic cells and then were after adherence further stimulated with recombinant IL-8. (D) $\beta 2$ integrins were determined by flow cytometry in resting neutrophils (basal value), neutrophils with adherent tethered PS + cargos (platelets or apoptotic LCL cells), or neutrophils with intracellular PS + cargos (platelets or apoptotic LCL cells) after further stimulation with fMLP or IL-8. Results (mean \pm SEM) are expressed as the percentage of basal value. Adapted from Ref. $(51,128)$. 
damage responses 1) signal, suggesting that remission might be associated with a block of the ability to activate autophagy and to release inflammatory NETs (147).

IL- $1 \beta$ generated via macrophage inflammasomes plays a critical role in atherosclerosis, and cholesterol crystals prompt in vivo NET generation. Macrophages exposed to NETs respond by activating the TH17 cell-dependent pathway that amplifies and sustains the recruitment of neutrophils within the atherosclerotic plaque (148). Similar self-sustaining positive feedback forward loops might be involved in the establishment and growth of lesions and in the atherothrombotic complications associated with diseases in which neutrophil activation is involved $(38,44$, 56, 58, 149-154).

Relatively small (less than $1 \mu$ ) urate aggregates are a normal finding in the fluids of patients with hyperuricemia and only a fraction of these subjects develops acute gouty arthritis. Microaggregate clearance by blood neutrophils and monocytes prevents the actual precipitation of crystals, their frustrated phagocytosis, and the generation of NETs (155). Phagocytosis is assisted by fractions of the complement cascade and by the negative acute phase protein, fetuin (155). Therefore, even in the case of crystal recognition, phagocytosis and NET generation represent alternative outcomes of neutrophil activation, which may eventually adjust negatively to each other, as it has been demonstrated extensively for microbial structures [e.g., see Ref. (156)].

Microparticles also trigger NETs generation, playing a role in the pathogenesis of diseases characterized by extensive vascular damage, such as lupus nephritis, systemic sclerosis, and preeclampsia (60, 157-160). Microparticles share signals with activated platelets and apoptotic cells, from which they often originate. Microparticle recognition involves a similar group of receptor/ligand pairs, including the direct or indirect recognition of PS and PS-associated moieties (90). However, the content of microparticles does not appear to be degraded in the phagolysosome. Microparticle constituents are often integrated within the phagocyte machinery and influences the cell function, differentiation, and activation state (161-168), indicating that internalized material is not routed to a conventional phagocytic route. Even synthetic particles induce NETs, and this effect is strictly dependent on their size (169). To the best of our knowledge, little is known on the possible action of microparticles on the ability of neutrophils to phagocytose particulate substrates.

\section{MECHANISMS OF THE CHOICE}

The size of the particulate dramatically influences the outcome of its interaction with neutrophils $(170,171)$. Neutrophils efficiently phagocytose several microorganisms. After internalization, neutrophil granules are rapidly mobilized via mechanisms dependent on small GTPases and on interacting proteins. Primary azurophilic granules, which contain preformed microbicidal moieties including myeloperoxidase and neutrophil elastase, eventually fuse with phagosomes (172). The phagocyte NADPH oxidase NOX2 complex assembles within the resulting phagolysosome, and electrons are transferred to molecular oxygen, with massive production of reactive oxygen species (ROS) into the lumen $(173,174)$. The presence of ROS combined with the neutrophil enzymes guarantees the killing of internalized microbes and the further degradation of the internalized particulate.

Myeloperoxidase, elastase, and ROS are in parallel key signals in the generation of NETs. In this case, signals that activate neutrophils lead to an oxidative burst and to the generation of ROS in the absence of a competent phagolysome. Thus, ROS cannot promote the focused release of neutrophil enzyme within the vesicle, contributing to dismantle the internalized cargo. ROS promote the release of the azurosome complex, which contains among other components myeloperoxidase and elastase, from the membrane of azurophilic granules into the cytosol. The complex then binds to and degrades the actin-based cytoskeleton. This event is a critical checkpoint.

(i) The degradation of the cytoskeleton is required to allow proteases to enter the nucleus $(13,18)$. Elastase and myeloperoxidase in particular concur to favor the decondensation of the chromatin via a pathway dependent on the ability of elastase to cleave histones but independent of the enzymatic activity of myeloperoxidase (17). Interference with the activity of elastase or complete absence of myeloperoxidase prevents the formation of NETs. When neutrophils have been previously engaged in phagocytosis, elastase and myeloperoxidase are sequestered within the phagolysome. They cannot reach the cytosol and eventually the nucleus and are not available for chromatin decondensation making it impossible for the phagocyte to generate NETs $(18,170)$.

(ii) Conversely, the integrity of the cytoskeleton is required to phagocytose particulate substrates. Neutrophils dismantle to generate NETs, the actin-based cytoskeleton, and are not competent anymore to phagocytose particulates. Small Rac GTPases, components of the NADPH oxidase NOX2 complex and required for the generation of NETs, regulate the cytoskeleton dynamics and adhesion $(175,176)$, providing a molecular link between the cytoskeleton remodeling and the requirement of neutrophil adhesion to solid substrates in vitro and in vivo for NETs generation (128).

NADPH oxidase activity is optimal at an intracellular $\mathrm{pH}$ of 7.5. An acute, transient drop in intracellular $\mathrm{pH}$, dependent on $\mathrm{H}+$ ions generated as a consequence of the NADPH oxidase activity, ensues the phagocytosis of opsonized bulky particulates (177) and acidic environments impair NET formation (178). Increased $\mathrm{pH}$ in contrast favors NET generation, possibly influencing the natural history of pancreatitis, where aggregated NETs occlude ducts and cause tissue injury $(178,179)$. Further studies are necessary to verify the effect of variation of the tightly regulated intracellular $\mathrm{pH}$ on the fate of neutrophils challenged with particulates.

Pathways leading to NET generation differ in terms of dependence on oxygen species, of kinetics of the process, and of the fate of the involved neutrophils, which can either die or survive after NET generation conserving at least some of their biological function $(13,180-182)$. Specifically MAPKs such as ERK and p38 regulate NOX2-dependent generation of NETs (183-185). The extent of activation of JNK/SAPK determines the response to synthetic and microbial stimuli, regulating the overall efficiency of ROS production and the ensuing NET generation 
(186). NET generation elicited by calcium ionophores relies on mitochondrial ROS and the calcium-activated small conductance potassium SK3 channel but is relatively independent of ERK activation $(185,187,188)$. The existence of independent pathways leading to the generation of NETs endowed with potent biological action in the microenvironment that might compensate one for the other $(13,19,182)$ supports the evolutionary importance of neutrophil activation. A ROS-independent, fast and vital pathway is apparently the first to be activated in neutrophils challenged with activated platelets and apoptotic cells. Depending on the environmental conditions, other outcomes can be envisaged.

The nucleus is not a passive target of the action of granular and cytosolic enzymes. At least two signals normally involved in chromatin architecture and function, DEK and HMGB1, actively regulate NET generation. Both molecules have a "double life." Besides their action in the nucleus, they can be extruded or actively released in the extracellular environment where they regulate the inflammatory response. DEK, a highly conserved phosphoprotein involved in the control of genomic stability, is both an autoantigen and a chemoattractant signal whose role has been so far only partially characterized (189). Neutrophils release DEK into the extracellular space, and its presence is necessary for NETs generation, possibly because it stabilizes NET architecture in the extracellular space (16). To the best of our knowledge, little is known on the possible action of DEK in regulating neutrophil phagocytosis.

HMGB1 is as well a non-histone protein with an architectural function in the living cells [see above and (135, 190-192)]. Released in the extracellular environment, it represents the prototypic and so far the best characterized DAMP/alarmin signal (193-195). HMGB1 is a potent inducer of autophagy (196) and NETs generation (58, 131). HMGB1 released by activated platelets, activated leukocytes, and necrotic cells influences leukocyte functions, favoring neoangiogenesis (197), a tumor-permissive environment in experimental models (198, 199) and-possibly via NET induction-favoring a prothrombotic state in tumor-bearing patients (135). HMGB1 is also an effective inhibitor of phagocytosis (200-203). It is tempting to hypothesize that cytosolic, extracellular and nuclear HMGB1 can act in a coordinated manner, facilitating the survival and the adoption of the most effective response of a neutrophil challenged with a phagocytic substrate. Further studies are needed to test this hypothesis.

\section{A METABOLIC SWITCH?}

Other mechanisms probably concur to explain the dichotomic nature of the neutrophil choice between phagocytosis and NET generation. Phagocytosis implies the sudden increase of the cell actual content depending on the ingestion of the phagocytic cargo with its own lipids, nucleic acids, proteins, etc. The metabolic pathways that allow the phagocyte to handle the further burden of internalized material have been only partially elucidated (204, 205). The fine regulation of the mitochondrial function appears of crucial importance, with the total mitochondrial membrane potential that directly impacts on the efficacy of the clearance in vivo, eventually leading to the termination of the apoptotic meal, i.e., to the failure of phagocytes that have internalized/are processing the prey to phagocytose further particulate substrates (206). A similar energetic constrain might restrict other potentially energyconsuming activities of the cell, such as initiation of the oxygen burst or the complete redistribution of the intracellular nuclear and granular content, which is a prerequisite of the release of NETs in the extracellular environment. Figure 2 depicts a schematic

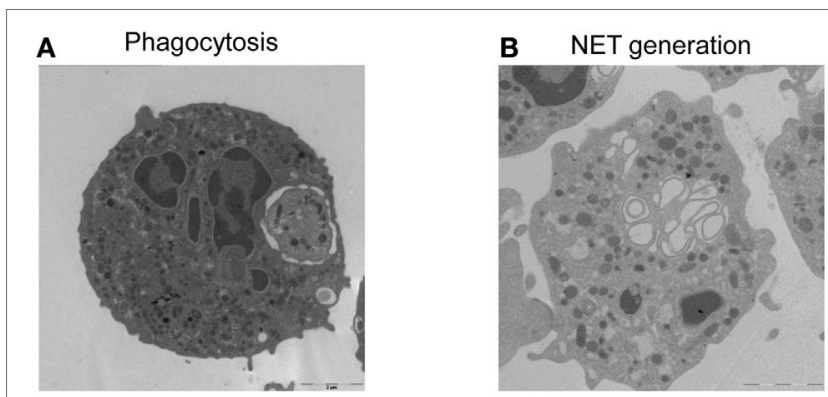

C

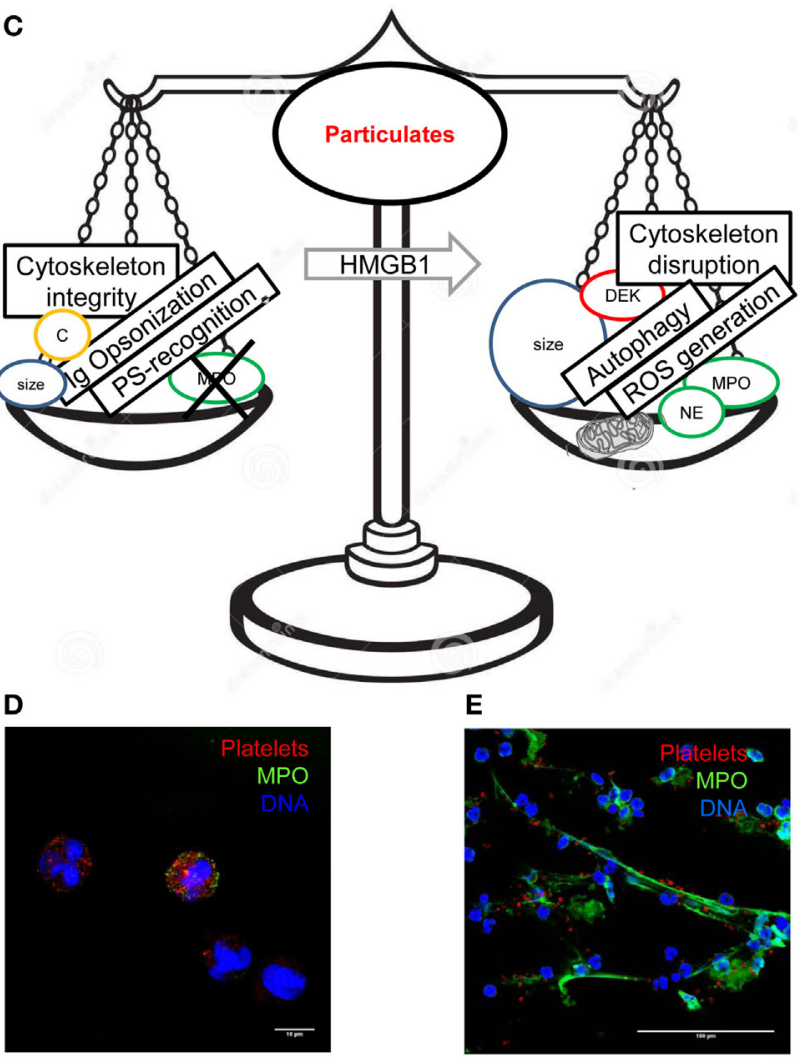

FIGURE 2 | Integration of multiple signals leads to the final decision of the neutrophils challenged with a bulky particulate substrates, whether to phagocytose it or to generate neutrophil extracellular traps (NETs). Phagocytosed blood platelets were revealed by transmission electron microscopy in blood neutrophils of patients with polycythemia vera (A) Neutrophils of healthy donors challenged with autologous activated platelets acquire a typical appearance at electron microscopy (B). Several factors regulate phagocytosis and NET generation differentially, prompting one event to negatively regulate the other $\mathbf{( C )}$. Internalization of red fluorescent platelets by neutrophils (D) and generation of extracellular threads of DNA (blue) decorated with myeloperoxidase (green color) was detected by confocal microscopy. (A,D) had originally been published in Ref. (68), (B) in Ref. (60), and (E) in Ref. (58). 
representation of events that might influence the decision of the neutrophil challenged with phagocytic substrates, whether to internalize and process it or to generate NETs. From the teleological point of view, to limit neutrophil reactivity after phagocytosis might restrict collateral damages caused by phagocytes persistently stimulated when their initial response has failed to clear the inflammatory noxa. Conversely, the systemic inflammatory response and enhanced thromboembolic risk, which are hallmarks of diseases associated with the failure of the phagocytic ability of neutrophils or macrophages, such as SLE, might thus reflect among other causes the lack of the calming effects of the phagocytic meal.

\section{REFERENCES}

1. Radic M, Marion TN. Neutrophil extracellular chromatin traps connect innate immune response to autoimmunity. Semin Immunopathol (2013) 35(4):465-80. doi:10.1007/s00281-013-0376-6

2. Grayson PC, Kaplan MJ. At the bench: neutrophil extracellular traps (NETs) highlight novel aspects of innate immune system involvement in autoimmune diseases. J Leukoc Biol (2016) 99(2):253-64. doi:10.1189/jlb.5BT0615-247R

3. Sorensen OE, Borregaard N. Neutrophil extracellular traps - the dark side of neutrophils. J Clin Invest (2016) 126(5):1612-20. doi:10.1172/JCI84538

4. Jaillon S, Peri G, Delneste Y, Fremaux I, Doni A, Moalli F, et al. The humoral pattern recognition receptor PTX3 is stored in neutrophil granules and localizes in extracellular traps. J Exp Med (2007) 204(4):793-804. doi:10.1084/ jem.20061301

5. Engelmann B, Massberg S. Thrombosis as an intravascular effector of innate immunity. Nat Rev Immunol (2013) 13(1):34-45. doi:10.1038/nri3345

6. Ramirez GA, Rovere-Querini P, Sabbadini MG, Manfredi AA. Parietal and intravascular innate mechanisms of vascular inflammation. Arthritis Res Ther (2015) 17(1):16. doi:10.1186/s13075-015-0528-2

7. Maugeri N, Manfredi AA. Tissue factor expressed by neutrophils: another piece in the vascular inflammation puzzle. Semin Thromb Hemost (2015) 41(7):728-36. doi:10.1055/s-0035-1564043

8. Erreni M, Manfredi AA, Garlanda C, Mantovani A, Rovere-Querini P. The long pentraxin PTX3: a prototypical sensor of tissue injury and a regulator of homeostasis. Immunol Rev (2017) 280(1):112-25. doi:10.1111/imr.12570

9. Mitsios A, Arampatzioglou A, Arelaki S, Mitroulis I, Ritis K. NETopathies? Unraveling the dark side of old diseases through neutrophils. Front Immunol (2016) 7:678. doi:10.3389/fimmu.2016.00678

10. Hahn J, Knopf J, Maueroder C, Kienhofer D, Leppkes M, Herrmann M. Neutrophils and neutrophil extracellular traps orchestrate initiation and resolution of inflammation. Clin Exp Rheumatol (2016) 34(4 Suppl 98):6-8.

11. Deniset JF, Kubes P. Recent advances in understanding neutrophils. F1000Res (2016) 5:2912. doi:10.12688/f1000research.9691.1

12. Jorch SK, Kubes P. An emerging role for neutrophil extracellular traps in noninfectious disease. Nat Med (2017) 23(3):279-87. doi:10.1038/nm.4294

13. Papayannopoulos V. Neutrophil extracellular traps in immunity and disease. Nat Rev Immunol (2017) 18:134-47. doi:10.1038/nri.2017.105

14. Neeli I, Dwivedi N, Khan S, Radic M. Regulation of extracellular chromatin release from neutrophils. J Innate Immun (2009) 1(3):194-201. doi:10.1159/ 000206974

15. Neeli I, Khan SN, Radic M. Histone deimination as a response to inflammatory stimuli in neutrophils. J Immunol (2008) 180(3):1895-902. doi:10.4049/ jimmunol.180.3.1895

16. Mor-Vaknin N, Saha A, Legendre M, Carmona-Rivera C, Amin MA, Rabquer BJ, et al. DEK-targeting DNA aptamers as therapeutics for inflammatory arthritis. Nat Commun (2017) 8:14252. doi:10.1038/ncomms14252

17. Papayannopoulos V, Metzler KD, Hakkim A, Zychlinsky A. Neutrophil elastase and myeloperoxidase regulate the formation of neutrophil extracellular traps. J Cell Biol (2010) 191(3):677-91. doi:10.1083/jcb.201006052

18. Metzler KD, Fuchs TA, Nauseef WM, Reumaux D, Roesler J, Schulze I, et al. Myeloperoxidase is required for neutrophil extracellular trap formation:

\section{AUTHOR CONTRIBUTIONS}

All authors listed have made substantial, direct, and intellectual contribution to the work and approved it for publication.

\section{FUNDING}

The work in the authors' laboratories is supported by the AIRC (IG 20351), the MIUR (2015MGBEM2_002), and the Ministero della Salute (RF_2011_02352291 and RF_2013_ 02358715).

implications for innate immunity. Blood (2011) 117(3):953-9. doi:10.1182/ blood-2010-06-290171

19. Metzler KD, Goosmann C, Lubojemska A, Zychlinsky A, Papayannopoulos V. A myeloperoxidase-containing complex regulates neutrophil elastase release and actin dynamics during NETosis. Cell Rep (2014) 8(3):883-96. doi:10.1016/j. celrep.2014.06.044

20. Massberg S, Grahl L, von Bruehl ML, Manukyan D, Pfeiler S, Goosmann C, et al. Reciprocal coupling of coagulation and innate immunity via neutrophil serine proteases. Nat Med (2010) 16(8):887-96. doi:10.1038/nm.2184

21. Ramirez GA, Maugeri N, Sabbadini MG, Rovere-Querini P, Manfredi AA. Intravascular immunity as a key to systemic vasculitis: a work in progress, gaining momentum. Clin Exp Immunol (2014) 175(2):150-66. doi:10.1111/ cei. 12223

22. Gaertner F, Massberg S. Blood coagulation in immunothrombosis-At the frontline of intravascular immunity. Semin Immunol (2016) 28(6):561-9. doi:10.1016/j.smim.2016.10.010

23. Pfeiler S, Stark K, Massberg S, Engelmann B. Propagation of thrombosis by neutrophils and extracellular nucleosome networks. Haematologica (2017) 102(2):206-13. doi:10.3324/haematol.2016.142471

24. Jimenez-Alcazar M, Rangaswamy C, Panda R, Bitterling J, Simsek YJ, Long AT, et al. Host DNases prevent vascular occlusion by neutrophil extracellular traps. Science (2017) 358(6367):1202-6. doi:10.1126/science.aam8897

25. Hepburn AL. The LE cell. Rheumatology (Oxford) (2001) 40(7):826-7. doi:10.1093/rheumatology/40.7.826

26. Pisetsky DS. The LE cell: crime scene or crime stopper? Arthritis Res Ther (2012) 14(3):120. doi:10.1186/ar3878

27. Bohm I. Flow cytometric analysis of the LE cell phenomenon. Autoimmunity (2004) 37(1):37-44. doi:10.1080/08916930310001630325

28. Compagno M, Gullstrand B, Jacobsen S, Eilertsen GO, Nilsson JA, Lood C, et al. The assessment of serum-mediated phagocytosis of necrotic material by polymorphonuclear leukocytes to diagnose and predict the clinical features of systemic lupus erythematosus: an observational longitudinal study. Arthritis Res Ther (2016) 18:44. doi:10.1186/s13075-016-0941-1

29. Magna M, Pisetsky DS. The role of cell death in the pathogenesis of SLE: is pyroptosis the missing link? Scand JImmunol (2015) 82(3):218-24. doi:10.1111/sji.12335

30. Galati G, Rovere P, Citterio G, Bondanza A, Scagliette U, Bucci E, et al. In vivo administration of GM-CSF promotes the clearance of apoptotic cells: effects on monocytes and polymorphonuclear leukocytes. J Leukoc Biol (2000) 67(2):174-82. doi:10.1002/jlb.67.2.174

31. Esmann L, Idel C, Sarkar A, Hellberg L, Behnen M, Moller S, et al. Phagocytosis of apoptotic cells by neutrophil granulocytes: diminished proinflammatory neutrophil functions in the presence of apoptotic cells. JImmunol (2010) 184(1):391-400. doi:10.4049/jimmunol.0900564

32. Hellberg L, Fuchs S, Gericke C, Sarkar A, Behnen M, Solbach W, et al. Proinflammatory stimuli enhance phagocytosis of apoptotic cells by neutrophil granulocytes. ScientificWorldJournal (2011) 11:2230-6. doi:10.1100/ 2011/413271

33. Sciorati C, Rigamonti E, Manfredi AA, Rovere-Querini P. Cell death, clearance and immunity in the skeletal muscle. Cell Death Differ (2016) 23(6):927-37. doi:10.1038/cdd.2015.171 
34. Capobianco A, Cottone L, Monno A, Manfredi AA, Rovere-Querini P. The peritoneum: healing, immunity, and diseases. J Pathol (2017) 243(2):137-47. doi:10.1002/path.4942

35. Nicolas-Avila JA, Adrover JM, Hidalgo A. Neutrophils in homeostasis, immunity, and cancer. Immunity (2017) 46(1):15-28. doi:10.1016/j.immuni. 2016.12.012

36. Gaertner F, Ahmad Z, Rosenberger G, Fan S, Nicolai L, Busch B, et al. Migrating platelets are mechano-scavengers that collect and bundle bacteria. Cell (2017) 171(6):1368-82.e23. doi:10.1016/j.cell.2017.11.001

37. Baldini M, Manfredi AA, Maugeri N. Targeting platelet-neutrophil interactions in giant-cell arteritis. Curr Pharm Des (2014) 20(4):567-74. doi:10.2174 /138161282004140213144840

38. Manfredi AA, Baldini M, Camera M, Baldissera E, Brambilla M, Peretti G, et al. Anti-TNFalpha agents curb platelet activation in patients with rheumatoid arthritis. Ann Rheum Dis (2016) 75(8):1511-20. doi:10.1136/annrheumdis2015-208442

39. McDonald B, Urrutia R, Yipp BG, Jenne CN, Kubes P. Intravascular neutrophil extracellular traps capture bacteria from the bloodstream during sepsis. Cell Host Microbe (2012) 12(3):324-33. doi:10.1016/j.chom.2012.06.011

40. Mauler M, Seyfert J, Haenel D, Seeba H, Guenther J, Stallmann D, et al. Platelet-neutrophil complex formation - a detailed in vitro analysis of murine and human blood samples. J Leukoc Biol (2016) 99(5):781-9. doi:10.1189/jlb. 3TA0315-082R

41. Peters MJ, Dixon G, Kotowicz KT, Hatch DJ, Heyderman RS, Klein NJ. Circulating platelet-neutrophil complexes represent a subpopulation of activated neutrophils primed for adhesion, phagocytosis and intracellular killing. Br J Haematol (1999) 106(2):391-9. doi:10.1046/j.1365-2141.1999.01553.x

42. Huo Y, Schober A, Forlow SB, Smith DF, Hyman MC, Jung S, et al. Circulating activated platelets exacerbate atherosclerosis in mice deficient in apolipoprotein E. Nat Med (2003) 9(1):61-7. doi:10.1038/nm810

43. Kornerup KN, Salmon GP, Pitchford SC, Liu WL, Page CP. Circulating platelet-neutrophil complexes are important for subsequent neutrophil activation and migration. JAppl Physiol (1985) (2010) 109(3):758-67. doi:10.1152/ japplphysiol.01086.2009

44. Maugeri N, Baldini M, Ramirez GA, Rovere-Querini P, Manfredi AA. Plateletleukocyte deregulated interactions foster sterile inflammation and tissue damage in immune-mediated vessel diseases. Thromb Res (2012) 129(3):267-73. doi:10.1016/j.thromres.2011.12.001

45. Lefer AM, Campbell B, Scalia R, Lefer DJ. Synergism between platelets and neutrophils in provoking cardiac dysfunction after ischemia and reperfusion: role of selectins. Circulation (1998) 98(13):1322-8. doi:10.1161/01.CIR.98. 13.1322

46. Singbartl K, Forlow SB, Ley K. Platelet, but not endothelial, P-selectin is critical for neutrophil-mediated acute postischemic renal failure. FASEB J (2001) 15(13):2337-44. doi:10.1096/fj.01-0199com

47. Theoret JF, Bienvenu JG, Kumar A, Merhi Y. P-selectin antagonism with recombinant p-selectin glycoprotein ligand-1 (rPSGL-Ig) inhibits circulating activated platelet binding to neutrophils induced by damaged arterial surfaces. J Pharmacol Exp Ther (2001) 298(2):658-64.

48. Sreeramkumar V, Adrover JM, Ballesteros I, Cuartero MI, Rossaint J, Bilbao I, et al. Neutrophils scan for activated platelets to initiate inflammation. Science (2014) 346(6214):1234-8. doi:10.1126/science.1256478

49. Kim SJ, Jenne CN. Role of platelets in neutrophil extracellular trap (NET) production and tissue injury. Semin Immunol (2016) 28(6):546-54. doi:10.1016/j. smim.2016.10.013

50. Evangelista V, Manarini S, Coller BS, Smyth SS. Role of P-selectin, beta2integrins, and Src tyrosine kinases in mouse neutrophil-platelet adhesion. J Thromb Haemost (2003) 1(5):1048-54.doi:10.1046/j.1538-7836.2003.00214.x

51. Maugeri N, Rovere-Querini P, Evangelista V, Covino C, Capobianco A, Bertilaccio MT, et al. Neutrophils phagocytose activated platelets in vivo: a phosphatidylserine, P-selectin and \{beta\}2 integrin-dependent cell clearance program. Blood (2009) 113:5254-65. doi:10.1182/blood-2008-09-180794

52. Evangelista V, Totani L, Manfredi AA, Maugeri N. Platelet-leukocyte interactions. In: Gresele P, Kleima NS, Lopez JA, Page CP, editors. Platelets in Thrombotic and Non-Thrombotic Disorders. Gewerbestrasse: Springer International Publishing (2016). p. 407-34. doi:10.1007/978-3-319-47462-5

53. Evangelista V, Pamuklar Z, Piccoli A, Manarini S, Dell'Elba G, Pecce R, et al. Src family kinases mediate neutrophil adhesion to adherent platelets. Blood (2007) 109(6):2461-9. doi:10.1182/blood-2006-06-029082
54. Piccardoni P, Manarini S, Federico L, Bagoly Z, Pecce R, Martelli N, et al. SRC-dependent outside-in signalling is a key step in the process of autoregulation of beta2 integrins in polymorphonuclear cells. Biochem J (2004) 380 (Pt 1):57-65. doi:10.1042/BJ20040151

55. Maugeri N, Rovere-Querini P, Evangelista V, Godino C, Demetrio M, Baldini $\mathrm{M}$, et al. An intense and short-lasting burst of neutrophil activation differentiates early acute myocardial infarction from systemic inflammatory syndromes. PLoS One (2012) 7(6):e39484. doi:10.1371/journal.pone.0039484

56. Maugeri N, Rovere-Querini P, Slavich M, Coppi G, Doni A, Bottazzi B, et al. Early and transient release of leukocyte pentraxin 3 during acute myocardial infarction. J Immunol (2011) 187(2):970-9. doi:10.4049/jimmunol.1100261

57. Maugeri N, de Gaetano G, Barbanti M, Donati MB, Cerletti C. Prevention of platelet-polymorphonuclear leukocyte interactions: new clues to the antithrombotic properties of parnaparin, a low molecular weight heparin. Haematologica (2005) 90(6):833-9.

58. Maugeri N, Campana L, Gavina M, Covino C, De Metrio M, Panciroli C, et al. Activated platelets present high mobility group box 1 to neutrophils, inducing autophagy and promoting the extrusion of neutrophil extracellular traps. J Thromb Haemost (2014) 12(12):2074-88. doi:10.1111/jth.12710

59. Evangelista V, Manarini S, Dell'Elba G, Martelli N, Napoleone E, Di Santo A, et al. Clopidogrel inhibits platelet-leukocyte adhesion and platelet-dependent leukocyte activation. Thromb Haemost (2005) 94(3):568-77.

60. Maugeri N, Rovere-Querini P, Baldini M, Baldissera E, Sabbadini MG, Bianchi ME, et al. Oxidative stress elicits platelet/leukocyte inflammatory interactions via HMGB1: a candidate for microvessel injury in sytemic sclerosis. Antioxid Redox Signal (2014) 20(7):1060-74. doi:10.1089/ars.2013.5298

61. Manfredi AA, Rovere-Querini P, D’Angelo A, Maugeri N. Low molecular weight heparins prevent the induction of autophagy of activated neutrophils and the formation of neutrophil extracellular traps. Pharmacol Res (2017) 123:146-56. doi:10.1016/j.phrs.2016.08.008

62. Stark K, Philippi V, Stockhausen S, Busse J, Antonelli A, Miller M, et al. Disulfide HMGB1 derived from platelets coordinates venous thrombosis in mice. Blood (2016) 128(20):2435-49. doi:10.1182/blood-2016-04-710632

63. Simon DI, Chen Z, Xu H, Li CQ, Dong J, McIntire LV, et al. Platelet glycoprotein ibalpha is a counterreceptor for the leukocyte integrin Mac-1 (CD11b/ CD18). J Exp Med (2000) 192(2):193-204. doi:10.1084/jem.192.2.193

64. Saffarzadeh M, Preissner KT. Moonlighting proteins dictate the crosstalk between thrombosis and innate immunity. J Thromb Haemost (2014) 12(12): 2070-3. doi:10.1111/jth.12754

65. Vogel S, Bodenstein R, Chen Q, Feil S, Feil R, Rheinlaender J, et al. Plateletderived HMGB1 is a critical mediator of thrombosis. J Clin Invest (2015) 125(12):4638-54. doi:10.1172/JCI81660

66. Weber C, Springer TA. Neutrophil accumulation on activated, surface-adherent platelets in flow is mediated by interaction of Mac-1 with fibrinogen bound to alphaIIbbeta3 and stimulated by platelet-activating factor. J Clin Invest (1997) 100(8):2085-93. doi:10.1172/JCI119742

67. Gardiner EE, De Luca M, McNally T, Michelson AD, Andrews RK, Berndt MC. Regulation of P-selectin binding to the neutrophil P-selectin counter-receptor P-selectin glycoprotein ligand-1 by neutrophil elastase and cathepsin G. Blood (2001) 98(5):1440-7. doi:10.1182/blood.V98.5.1440

68. Maugeri N, Malato S, Femia EA, Pugliano M, Campana L, Lunghi F, et al. Clearance of circulating activated platelets in polycythemia vera and essential thrombocythemia. Blood (2011) 118(12):3359-66. doi:10.1182/blood2011-02-337337

69. Ma R, Xie R, Yu C, Si Y, Wu X, Zhao L, et al. Phosphatidylserine-mediated platelet clearance by endothelium decreases platelet aggregates and procoagulant activity in sepsis. Sci Rep (2017) 7(1):4978. doi:10.1038/s41598-017-04773-8

70. Maugeri N, Rovere-Querini P, Manfredi AA. Disruption of a regulatory network consisting of neutrophils and platelets fosters persisting inflammation in rheumatic diseases. Front Immunol (2016) 7:182. doi:10.3389/fimmu. 2016.00182

71. Hoffmann PR, deCathelineau AM, Ogden CA, Leverrier Y, Bratton DL, Daleke DL, et al. Phosphatidylserine (PS) induces PS receptor-mediated macropinocytosis and promotes clearance of apoptotic cells. J Cell Biol (2001) 155(4):649-59. doi:10.1083/jcb.200108080

72. Henson PM, Bratton DL, Fadok VA. Apoptotic cell removal. Curr Biol (2001) 11(19):R795-805. doi:10.1016/S0960-9822(01)00474-2

73. Toda S, Hanayama R, Nagata S. Two-step engulfment of apoptotic cells. Mol Cell Biol (2012) 32(1):118-25. doi:10.1128/MCB.05993-11 
74. Nishi C, Toda S, Segawa K, Nagata S. Tim4- and MerTK-mediated engulfment of apoptotic cells by mouse resident peritoneal macrophages. Mol Cell Biol (2014) 34(8):1512-20. doi:10.1128/MCB.01394-13

75. Bilyy RO, Shkandina T, Tomin A, Munoz LE, Franz S, Antonyuk V, et al. Macrophages discriminate glycosylation patterns of apoptotic cell-derived microparticles. J Biol Chem (2012) 287(1):496-503. doi:10.1074/jbc.M111. 273144

76. Nagata S, Suzuki J, Segawa K, Fujii T. Exposure of phosphatidylserine on the cell surface. Cell Death Differ (2016) 23(6):952-61. doi:10.1038/cdd.2016.7

77. Choo HJ, Kholmukhamedov A, Zhou C, Jobe S. Inner mitochondrial membrane disruption links apoptotic and agonist-initiated phosphatidylserine externalization in platelets. Arterioscler Thromb Vasc Biol (2017) 37(8): 1503-12. doi:10.1161/ATVBAHA.117.309473

78. Elliott MR, Ravichandran KS. The dynamics of apoptotic cell clearance. Dev Cell (2016) 38(2):147-60. doi:10.1016/j.devcel.2016.06.029

79. Manfredi AA, Rovere-Querini P, Maugeri N. Dangerous connections: neutrophils and the phagocytic clearance of activated platelets. Curr Opin Hematol (2010) 17(1):3-8. doi:10.1097/MOH.0b013e3283324f97

80. Kagan VE, Gleiss B, Tyurina YY, Tyurin VA, Elenstrom-Magnusson C, Liu SX, et al. A role for oxidative stress in apoptosis: oxidation and externalization of phosphatidylserine is required for macrophage clearance of cells undergoing Fas-mediated apoptosis. J Immunol (2002) 169(1):487-99. doi:10.4049/ jimmunol.169.1.487

81. Tyurin VA, Balasubramanian K, Winnica D, Tyurina YY, Vikulina AS, He RR, et al. Oxidatively modified phosphatidylserines on the surface of apoptotic cells are essential phagocytic 'eat-me' signals: cleavage and inhibition of phagocytosis by Lp-PLA2. Cell Death Differ (2014) 21(5):825-35. doi:10.1038/ cdd.2014.1

82. Chang MK, Bergmark C, Laurila A, Horkko S, Han KH, Friedman P, et al. Monoclonal antibodies against oxidized low-density lipoprotein bind to apoptotic cells and inhibit their phagocytosis by elicited macrophages: evidence that oxidation-specific epitopes mediate macrophage recognition. Proc Natl Acad Sci U S A (1999) 96(11):6353-8. doi:10.1073/pnas.96.11.6353

83. Mukundan L, Odegaard JI, Morel CR, Heredia JE, Mwangi JW, RicardoGonzalez RR, et al. PPAR-delta senses and orchestrates clearance of apoptotic cells to promote tolerance. Nat Med (2009) 15(11):1266-72. doi:10.1038/ nm.2048

84. AG N, Bensinger SJ, Hong C, Beceiro S, Bradley MN, Zelcer N, et al. Apoptotic cells promote their own clearance and immune tolerance through activation of the nuclear receptor LXR. Immunity (2009) 31(2):245-58. doi:10.1016/j. immuni.2009.06.018

85. Tsiantoulas D, Perkmann T, Afonyushkin T, Mangold A, Prohaska TA, PapacMilicevic N, et al. Circulating microparticles carry oxidation-specific epitopes and are recognized by natural IgM antibodies. J Lipid Res (2015) 56(2):440-8. doi:10.1194/jlr.P054569

86. Kimani SG, Geng K, Kasikara C, Kumar S, Sriram G, Wu Y, et al. Contribution of defective PS recognition and efferocytosis to chronic inflammation and autoimmunity. Front Immunol (2014) 5:566. doi:10.3389/fimmu.2014.00566

87. Binder CJ, Papac-Milicevic N, Witztum JL. Innate sensing of oxidationspecific epitopes in health and disease. Nat Rev Immunol (2016) 16(8):485-97. doi:10.1038/nri.2016.63

88. Biermann M, Maueroder C, Brauner JM, Chaurio R, Janko C, Herrmann M, et al. Surface code - biophysical signals for apoptotic cell clearance. Phys Biol (2013) 10(6):065007. doi:10.1088/1478-3975/10/6/065007

89. Penberthy KK, Ravichandran KS. Apoptotic cell recognition receptors and scavenger receptors. Immunol Rev (2016) 269(1):44-59. doi:10.1111/ imr. 12376

90. Happonen KE, Tran S, Morgelin M, Prince R, Calzavarini S, AngelilloScherrer A, et al. The Gas6-Axl protein interaction mediates endothelial uptake of platelet microparticles. J Biol Chem (2016) 291(20):10586-601. doi:10.1074/jbc.M115.699058

91. Tjwa M, Bellido-Martin L, Lin Y, Lutgens E, Plaisance S, Bono F, et al. Gas6 promotes inflammation by enhancing interactions between endothelial cells, platelets, and leukocytes. Blood (2008) 111(8):4096-105. doi:10.1182/ blood-2007-05-089565

92. Guignant C, Venet F, Planel S, Demaret J, Gouel-Cheron A, Nougier C, et al. Increased MerTK expression in circulating innate immune cells of patients with septic shock. Intensive Care Med (2013) 39(9):1556-64. doi:10.1007/ s00134-013-3006-9
93. Manfredi AA, Rovere P, Galati G, Heltai S, Bozzolo E, Soldini L, et al. Apoptotic cell clearance in systemic lupus erythematosus. I. Opsonization by antiphospholipid antibodies. Arthritis Rheum (1998) 41(2):205-14. doi:10.1002/1529-0131(199802)41:2<215::AID-ART5>3.0.CO;2-0

94. Manfredi AA, Rovere P, Heltai S, Galati G, Nebbia G, Tincani A, et al. Apoptotic cell clearance in systemiclupus erythematosus:II. Rolefor the beta2glycoprotein I. Arthritis Rheum (1998) 41:215-23. doi:10.1002/1529-0131 (199802) 41:2<215::AID-ART5>3.0.CO;2-X

95. Bondanza A, Sabbadini MG, Pellegatta F, Zimmermann VS, Tincani A, Balestrieri G, et al. Anti-beta2 glycoprotein I antibodies prevent the De-activation of platelets and sustain their phagocytic clearance. J Autoimmun (2000) 15(4):469-77. doi:10.1006/jaut.2000.0449

96. Bondanza A, Manfredi AA, Zimmermann VS, Iannacone M, Tincani A, Balestrieri G, et al. Anti-beta2 glycoprotein I antibodies cause inflammation and recruit dendritic cells in platelet clearance. Thromb Haemost (2001) 86(5):1257-63.

97. Manfredi AA, Rovere-Querini P, Bottazzi B, Garlanda C, Mantovani A. Pentraxins, humoral innate immunity and tissue injury. Curr Opin Immunol (2008) 20(5):538-44. doi:10.1016/j.coi.2008.05.004

98. Rovere P, Peri G, Fazzini F, Bottazzi B, Doni A, Bondanza A, et al. The long pentraxin PTX3 binds to apoptotic cells and regulates their clearance by antigen-presenting dendritic cells. Blood (2000) 96(13):4300-6.

99. Bondanza A, Rovere-Querini P, Zimmermann VS, Balestrieri G, Tincani A, Sabbadini MG, et al. Requirement for dendritic cells in the establishment of anti-phospholipid antibodies. Autoimmunity (2007) 40(4):302-6. doi:10.1080/ 08916930701356572

100. Baruah P, Propato A, Dumitriu IE, Rovere-Querini P, Russo V, Fontana R, et al. The pattern recognition receptor PTX3 is recruited at the synapse between dying and dendritic cells, and edits the cross-presentation of self, viral, and tumor antigens. Blood (2006) 107(1):151-8. doi:10.1182/blood-2005-03-1112

101. Fadok VA, Voelker DR, Campbell PA, Cohen JJ, Bratton DL, Henson PM Exposure of phosphatidylserine on the surface of apoptotic lymphocytes triggers specific recognition and removal by macrophages. J Immunol (1992) 148(7):2207-16.

102. Fadok VA, Bratton DL, Konowal A, Freed PW, Westcott JY, Henson PM. Macrophages that have ingested apoptotic cells in vitro inhibit proinflammatory cytokine production through autocrine/paracrine mechanisms involving TGF-beta, PGE2, and PAF. JClin Invest (1998) 101(4):890-8. doi:10.1172/JCI1112

103. Voll RE, Herrmann M, Roth EA, Stach C, Kalden JR, Girkontaite I. Immunosuppressive effects of apoptotic cells. Nature (1997) 390(6658): 350-1. doi:10.1038/37022

104. Serhan CN, Savill J. Resolution of inflammation: the beginning programs the end. Nat Immunol (2005) 6(12):1191-7. doi:10.1038/ni1276

105. Szondy Z, Sarang Z, Kiss B, Garabuczi E, Koroskenyi K. Anti-inflammatory mechanisms triggered by apoptotic cells during their clearance. Front Immunol (2017) 8:909. doi:10.3389/fimmu.2017.00909

106. Serhan CN. Discovery of specialized pro-resolving mediators marks the dawn of resolution physiology and pharmacology. Mol Aspects Med (2017) 58:1-11. doi:10.1016/j.mam.2017.03.001

107. Bosurgi L, Cao YG, Cabeza-Cabrerizo M, Tucci A, Hughes LD, Kong Y, et al. Macrophage function in tissue repair and remodeling requires IL-4 or IL-13 with apoptotic cells. Science (2017) 356(6342):1072-6. doi:10.1126/science. aai8132

108. Bosurgi L, Manfredi AA, Rovere-Querini P. Macrophages in injured skeletal muscle: a perpetuum mobile causing and limiting fibrosis, prompting or restricting resolution and regeneration. Front Immunol (2011) 2:62. doi:10.3389/fimmu.2011.00062

109. Bosurgi L, Corna G, Vezzoli M, Touvier T, Cossu G, Manfredi AA, et al. Transplanted mesoangioblasts require macrophage IL-10 for survival in a mouse model of muscle injury. J Immunol (2012) 188(12):6267-77. doi:10.4049/jimmunol.1102680

110. Bosurgi L, Brunelli S, Rigamonti E, Monno A, Manfredi AA, Rovere-Querini P. Vessel-associated myogenic precursors control macrophage activation and clearance of apoptotic cells. Clin Exp Immunol (2015) 179(1):62-7. doi:10.1111/ cei. 12356

111. Du H, Shih CH, Wosczyna MN, Mueller AA, Cho J, Aggarwal A, et al. Macrophage-released ADAMTS1 promotes muscle stem cell activation. Nat Commun (2017) 8(1):669. doi:10.1038/s41467-017-00522-7 
112. Herrmann M, Voll RE, Zoller OM, Hagenhofer M, Ponner BB, Kalden JR. Impaired phagocytosis of apoptotic cell material by monocyte-derived macrophages from patients with systemic lupus erythematosus. Arthritis Rheum (1998) 41(7):1241-50. doi:10.1002/1529-0131(199807)41:7<1241::AIDART15>3.0.CO;2-H

113. Baumann I, Kolowos W, Voll RE, Manger B, Gaipl U, Neuhuber WL, et al. Impaired uptake of apoptotic cells into tingible body macrophages in germinal centers of patients with systemic lupus erythematosus. Arthritis Rheum (2002) 46(1):191-201. doi:10.1002/1529-0131(200201)46:1<191::AIDART10027>3.0.CO;2-K

114. Bondanza A, Zimmermann VS, Rovere-Querini P, Turnay J, Dumitriu IE, Stach CM, et al. Inhibition of phosphatidylserine recognition heightens the immunogenicity of irradiated lymphoma cells in vivo. J Exp Med (2004) 200(9):1157-65. doi:10.1084/jem.20040327

115. Munoz LE, Lauber K, Schiller M, Manfredi AA, Herrmann M. The role of defective clearance of apoptotic cells in systemic autoimmunity. Nat Rev Rheumatol (2010) 6(5):280-9. doi:10.1038/nrrheum.2010.46

116. Birge RB, Boeltz S, Kumar S, Carlson J, Wanderley J, Calianese D, et al. Phosphatidylserine is a global immunosuppressive signal in efferocytosis, infectious disease, and cancer. Cell Death Differ (2016) 23(6):962-78. doi:10.1038/cdd.2016.11

117. Bellone M, Iezzi G, Rovere P, Galati G, Ronchetti A, Protti MP, et al. Processing of engulfed apoptotic bodies yields $\mathrm{T}$ cell epitopes. JImmunol (1997) 159(11):5391-9.

118. Rovere P, Vallinoto C, Bondanza A, Crosti MC, Rescigno M, RicciardiCastagnoli $\mathrm{P}$, et al. Bystander apoptosis triggers dendritic cell maturation and antigen-presenting function. J Immunol (1998) 161(9):4467-71.

119. Rovere P, Sabbadini MG, Vallinoto C, Fascio U, Rescigno M, Crosti MC, et al. Dendritic cell presentation of antigens from apoptotic cells in a pro-inflammatory context: role of opsonizing anti-beta 2 glycoprotein I antibodies. Arthritis Rheum (1999) 42:1412-20. doi:10.1002/1529-0131(199907) 42:7<1412::AID-ANR15>3.0.CO;2-T

120. Bondanza A, Zimmermann VS, Dell'Antonio G, Dal Cin E, Capobianco A, Sabbadini MG, et al. Cutting edge: dissociation between autoimmune response and clinical disease after vaccination with dendritic cells. J Immunol (2003) 170(1):24-7. doi:10.4049/jimmunol.170.1.24

121. Harbers SO, Crocker A, Catalano G, D’Agati V, Jung S, Desai DD, et al. Antibody-enhanced cross-presentation of self antigen breaks $\mathrm{T}$ cell tolerance. J Clin Invest (2007) 117(5):1361-9. doi:10.1172/JCI29470

122. Sciorati C, Monno A, Ascherman DP, Seletti E, Manfredi AA, Rovere-Querini P. Required role of apoptotic myogenic precursors and toll-like receptor stimulation for the establishment of autoimmune myositis in experimental murine models. Arthritis Rheumatol (2015) 67(3):809-22. doi:10.1002/ art. 38985

123. Yatim N, Cullen S, Albert ML. Dying cells actively regulate adaptive immune responses. Nat Rev Immunol (2017) 17(4):262-75. doi:10.1038/nri.2017.9

124. Cruz FM, Colbert JD, Merino E, Kriegsman BA, Rock KL. The biology and underlying mechanisms of cross-presentation of exogenous antigens on MHC-I molecules. Annu Rev Immunol (2017) 35:149-76. doi:10.1146/ annurev-immunol-041015-055254

125. Blander JM. The many ways tissue phagocytes respond to dying cells. Immunol Rev (2017) 277(1):158-73. doi:10.1111/imr.12537

126. Smith CK, Kaplan MJ. The role of neutrophils in the pathogenesis of systemic lupus erythematosus. Curr Opin Rheumatol (2015) 27(5):448-53. doi:10.1097/BOR.0000000000000197

127. Huang $\mathrm{W}$, Wu J, Yang $\mathrm{H}$, Xiong $\mathrm{Y}$, Jiang R, Cui T, et al. Milk fat globule-EGF factor 8 suppresses the aberrant immune response of systemic lupus erythematosus-derived neutrophils and associated tissue damage. Cell Death Differ (2017) 24(2):263-75. doi:10.1038/cdd.2016.115

128. Manfredi AA, Covino C, Rovere-Querini P, Maugeri N. Instructive influences of phagocytic clearance of dying cells on neutrophil extracellular trap generation. Clin Exp Immunol (2015) 179(1):24-9. doi:10.1111/cei.12320

129. Clark SR, Ma AC, Tavener SA, McDonald B, Goodarzi Z, Kelly MM, et al. Platelet TLR4 activates neutrophil extracellular traps to ensnare bacteria in septic blood. Nat Med (2007) 13(4):463-9. doi:10.1038/nm1565

130. Maugeri N, Franchini S, Campana L, Baldini M, Ramirez GA, Sabbadini MG, et al. Circulating platelets as a source of the damage-associated molecular pattern HMGB1 in patients with systemic sclerosis. Autoimmunity (2012) 45(8):584-7. doi:10.3109/08916934.2012.719946
131. Tadie JM, Bae HB, Jiang S, Park DW, Bell CP, Yang H, et al. HMGB1 promotes neutrophil extracellular trap formation through interactions with toll-like receptor 4. Am J Physiol Lung Cell Mol Physiol (2013) 304(5):L342-9. doi:10.1152/ajplung.00151.2012

132. Liaw PC, Ito T, Iba T, Thachil J, Zeerleder S. DAMP and DIC: the role of extracellular DNA and DNA-binding proteins in the pathogenesis of DIC. Blood Rev (2016) 30(4):257-61. doi:10.1016/j.blre.2015.12.004

133. Ma YH, Ma TT, Wang C, Wang H, Chang DY, Chen M, et al. High-mobility group box 1 potentiates antineutrophil cytoplasmic antibody-inducing neutrophil extracellular traps formation. Arthritis Res Ther (2016) 18:2. doi:10.1186/s13075-015-0903-Z

134. Huang H, Tohme S, Al-Khafaji AB, Tai S, Loughran P, Chen L, et al. Damageassociated molecular pattern-activated neutrophil extracellular trap exacerbates sterile inflammatory liver injury. Hepatology (2015) 62(2):600-14. doi:10.1002/hep.27841

135. Bianchi ME, Crippa MP, Manfredi AA, Mezzapelle R, Rovere Querini P, Venereau E. High-mobility group box 1 protein orchestrates responses to tissue damage via inflammation, innate and adaptive immunity, and tissue repair. Immunol Rev (2017) 280(1):74-82. doi:10.1111/imr.12601

136. Maugeri N, Rovere-Querini P, Baldini M, Sabbadini MG, Manfredi AA. Translational mini-review series on immunology of vascular disease: mechanisms of vascular inflammation and remodelling in systemic vasculitis. Clin Exp Immunol (2009) 156(3):395-404. doi:10.1111/j.1365-2249.2009.03921.x

137. Birge RB, Ucker DS. Innate apoptotic immunity: the calming touch of death. Cell Death Differ (2008) 15(7):1096-102. doi:10.1038/cdd.2008.58

138. Munoz LE, Leppkes M, Fuchs TA, Hoffmann M, Herrmann M. Missing in action - the meaning of cell death in tissue damage and inflammation. Immunol Rev (2017) 280(1):26-40. doi:10.1111/imr.12569

139. Hachicha M, Naccache PH, McColl SR. Inflammatory microcrystals differentially regulate the secretion of macrophage inflammatory protein 1 and interleukin 8 by human neutrophils: a possible mechanism of neutrophil recruitment to sites of inflammation in synovitis. J Exp Med (1995) 182(6):2019-25. doi:10.1084/jem.182.6.2019

140. Schauer C, Janko C, Munoz LE, Zhao Y, Kienhofer D, Frey B, et al. Aggregated neutrophil extracellular traps limit inflammation by degrading cytokines and chemokines. Nat Med (2014) 20(5):511-7. doi:10.1038/nm.3547

141. Sil P, Wicklum H, Surell C, Rada B. Macrophage-derived IL-1beta enhances monosodium urate crystal-triggered NET formation. Inflamm Res (2017) 66(3):227-37. doi:10.1007/s00011-016-1008-0

142. Desai J, Steiger S, Anders HJ. Molecular pathophysiology of gout. Trends Mol Med (2017) 23(8):756-68. doi:10.1016/j.molmed.2017.06.005

143. Schett G, Schauer C, Hoffmann M, Herrmann M. Why does the gout attack stop? A roadmap for the immune pathogenesis of gout. RMD Open (2015) 1(Suppl 1):e000046. doi:10.1136/rmdopen-2015-000046

144. Sil P, Hayes CP, Reaves BJ, Breen P, Quinn S, Sokolove J, et al. P2Y6 receptor antagonist MRS2578 inhibits neutrophil activation and aggregated neutrophil extracellular trap formation induced by gout-associated monosodium urate crystals. J Immunol (2017) 198(1):428-42. doi:10.4049/ jimmunol.1600766

145. Mitroulis I, Kambas K, Chrysanthopoulou A, Skendros P, Apostolidou E, Kourtzelis I, et al. Neutrophil extracellular trap formation is associated with IL-1beta and autophagy-related signaling in gout. PLoS One (2011) 6(12):e29318. doi:10.1371/journal.pone.0029318

146. Apostolidou E, Skendros P, Kambas K, Mitroulis I, Konstantinidis T, Chrysanthopoulou A, et al. Neutrophil extracellular traps regulate IL-1betamediated inflammation in familial Mediterranean fever. Ann Rheum Dis (2016) 75(1):269-77. doi:10.1136/annrheumdis-2014-205958

147. Skendros P, Chrysanthopoulou A, Rousset F, Kambas K, Arampatzioglou A, Mitsios A, et al. Regulated in development and DNA damage responses 1 (REDD1) links stress with IL-1beta-mediated familial Mediterranean fever attack through autophagy-driven neutrophil extracellular traps. J Allergy Clin Immunol (2017) 140(5):1378-87.e13. doi:10.1016/j.jaci.2017.02.021

148. Warnatsch A, Ioannou M, Wang Q, Papayannopoulos V. Inflammation. Neutrophil extracellular traps license macrophages for cytokine production in atherosclerosis. Science (2015) 349(6245):316-20. doi:10.1126/science. aaa8064

149. Buffon A, Biasucci LM, Liuzzo G, D’Onofrio G, Crea F, Maseri A. Widespread coronary inflammation in unstable angina. N Engl J Med (2002) 347(1):5-12. doi:10.1056/NEJMoa012295 
150. Maugeri N, Baldini M, Rovere-Querini P, Maseri A, Sabbadini MG, Manfredi AA. Leukocyte and platelet activation in patients with giant cell arteritis and polymyalgia rheumatica: a clue to thromboembolic risks? Autoimmunity (2009) 42(4):386-8. doi:10.1080/08916930902832629

151. Knight JS, Luo W, O’Dell AA, Yalavarthi S, Zhao W, Subramanian V, et al. Peptidylarginine deiminase inhibition reduces vascular damage and modulates innate immune responses in murine models of atherosclerosis. Circ Res (2014) 114(6):947-56. doi:10.1161/CIRCRESAHA.114.303312

152. Stakos DA, Kambas K, Konstantinidis T, Mitroulis I, Apostolidou E, Arelaki S, et al. Expression of functional tissue factor by neutrophil extracellular traps in culprit artery of acute myocardial infarction. Eur Heart J (2015) 36(22):1405-14. doi:10.1093/eurheartj/ehv007

153. Mangold A, Alias S, Scherz T, Hofbauer T, Jakowitsch J, Panzenbock A, et al. Coronary neutrophil extracellular trap burden and deoxyribonuclease activity in ST-elevation acute coronary syndrome are predictors of ST-segment resolution and infarct size. Circ Res (2015) 116(7):1182-92. doi:10.1161/ CIRCRESAHA.116.304944

154. Garcia-Prieto J, Villena-Gutierrez R, Gomez M, Bernardo E, Pun-Garcia A, Garcia-Lunar I, et al. Neutrophil stunning by metoprolol reduces infarct size. Nat Commun (2017) 8:14780. doi:10.1038/ncomms 14780

155. Pieterse E, Jeremic I, Czegley C, Weidner D, Biermann MH, Veissi S, et al. Bloodborne phagocytes internalize urate microaggregates and prevent intravascular NETosis by urate crystals. Sci Rep (2016) 6:38229. doi:10.1038/srep38229

156. Johnson CJ, Kernien JF, Hoyer AR, Nett JE. Mechanisms involved in the triggering of neutrophil extracellular traps (NETs) by Candida glabrata during planktonic and biofilm growth. Sci Rep (2017) 7(1):13065. doi:10.1038/ s41598-017-13588-6

157. Gupta AK, Hasler P, Holzgreve W, Gebhardt S, Hahn S. Induction of neutrophil extracellular DNA lattices by placental microparticles and IL-8 and their presence in preeclampsia. Hum Immunol (2005) 66(11):1146-54. doi:10.1016/j.humimm.2005.11.003

158. Rovere-Querini P, Castiglioni MT, Sabbadini MG, Manfredi AA. Signals of cell death and tissue turnover during physiological pregnancy, pre-eclampsia, and autoimmunity. Autoimmunity (2007) 40(4):290-4. doi:10.1080/ 08916930701358834

159. Dieker J, Tel J, Pieterse E, Thielen A, Rother N, Bakker M, et al. Circulating apoptotic microparticles in systemic lupus erythematosus patients drive the activation of dendritic cell subsets and prime neutrophils for NETosis. Arthritis Rheumatol (2016) 68(2):462-72. doi:10.1002/art.39417

160. Rother N, Pieterse E, Lubbers J, Hilbrands L, van der Vlag J. Acetylated histones in apoptotic microparticles drive the formation of neutrophil extracellular traps in active lupus nephritis. Front Immunol (2017) 8:1136. doi:10.3389/fimmu.2017.01136

161. Sadallah S, Schmied L, Eken C, Charoudeh HN, Amicarella F, Schifferli JA. Platelet-derived ectosomes reduce NK cell function. JImmunol (2016) 197(5):1663-71. doi:10.4049/jimmunol.1502658

162. Kang T, Jones TM, Naddell C, Bacanamwo M, Calvert JW, Thompson WE, et al. Adipose-derived stem cells induce angiogenesis via microvesicle transport of miRNA-31. Stem Cells Transl Med (2016) 5(4):440-50. doi:10.5966/ sctm.2015-0177

163. Hayakawa K, Esposito E, Wang X, Terasaki Y, Liu Y, Xing C, et al. Transfer of mitochondria from astrocytes to neurons after stroke. Nature (2016) 535(7613):551-5. doi:10.1038/nature18928

164. MichaelJV, WurtzelJGT, Mao GF, Rao AK, Kolpakov MA, Sabri A, et al. Platelet microparticles infiltrating solid tumors transfer miRNAs that suppress tumor growth. Blood (2017) 130(5):567-80. doi:10.1182/blood-2016-11-751099

165. Sansone P, Berishaj M, Rajasekhar VK, Ceccarelli C, Chang Q, Strillacci A, et al. Evolution of cancer stem-like cells in endocrine-resistant metastatic breast cancers is mediated by stromal microvesicles. Cancer Res (2017) 77(8):1927-41. doi:10.1158/0008-5472.CAN-16-2129

166. Collino F, Pomatto M, Bruno S, Lindoso RS, Tapparo M, Sicheng W, et al. Exosome and microvesicle-enriched fractions isolated from mesenchymal stem cells by gradient separation showed different molecular signatures and functions on renal tubular epithelial cells. Stem Cell Rev (2017) 13(2):226-43. doi:10.1007/s12015-016-9713-1

167. Mahrouf-Yorgov M, Augeul L, Da Silva CC, Jourdan M, Rigolet M, Manin S, et al. Mesenchymal stem cells sense mitochondria released from damaged cells as danger signals to activate their rescue properties. Cell Death Differ (2017) 24(7):1224-38. doi:10.1038/cdd.2017.51
168. Morrison TJ, Jackson MV, Cunningham EK, Kissenpfennig A, McAuley DF, O'Kane CM, et al. Mesenchymal stromal cells modulate macrophages in clinically relevant lung injury models by extracellular vesicle mitochondrial transfer. Am J Respir Crit Care Med (2017) 196(10):1275-86. doi:10.1164/ rccm.201701-0170OC

169. Munoz LE, Bilyy R, Biermann MH, Kienhofer D, Maueroder C, Hahn J, et al. Nanoparticles size-dependently initiate self-limiting NETosis-driven inflammation. Proc Natl Acad Sci U S A (2016) 113(40):E5856-65. doi:10.1073/ pnas. 1602230113

170. Branzk N, Lubojemska A, Hardison SE, Wang Q, Gutierrez MG, Brown GD, et al. Neutrophils sense microbe size and selectively release neutrophil extracellular traps in response to large pathogens. Nat Immunol (2014) 15(11):1017-25. doi:10.1038/ni.2987

171. Warnatsch A, Tsourouktsoglou TD, Branzk N, Wang Q, Reincke S, Herbst S, et al. Reactive oxygen species localization programs inflammation to clear microbes of different size. Immunity (2017) 46(3):421-32. doi:10.1016/j. immuni.2017.02.013

172. Ramadass M, Catz SD. Molecular mechanisms regulating secretory organelles and endosomes in neutrophils and their implications for inflammation. Immunol Rev (2016) 273(1):249-65. doi:10.1111/imr.12452

173. Nordenfelt P, Tapper H. Phagosome dynamics during phagocytosis by neutrophils. J Leukoc Biol (2011) 90(2):271-84. doi:10.1189/jlb.0810457

174. Levin R, Grinstein S, Canton J. The life cycle of phagosomes: formation, maturation, and resolution. Immunol Rev (2016) 273(1):156-79. doi:10.1111/ imr.12439

175. Gavillet M, Martinod K, Renella R, Wagner DD, Williams DA. A key role for Rac and Pak signaling in neutrophil extracellular traps (NETs) formation defines a new potential therapeutic target. Am J Hematol (2017) 93:269-76. doi:10.1002/ajh. 24970

176. Stojkov D, Amini P, Oberson K, Sokollik C, Duppenthaler A, Simon HU, et al. ROS and glutathionylation balance cytoskeletal dynamics in neutrophil extracellular trap formation. J Cell Biol (2017) 216(12):4073-90. doi:10.1083/ jcb. 201611168

177. Capasso M, DeCoursey TE, Dyer MJ. pH regulation and beyond: unanticipated functions for the voltage-gated proton channel, HVCN1. Trends Cell Biol (2011) 21(1):20-8. doi:10.1016/j.tcb.2010.09.006

178. Maueroder C, Mahajan A, Paulus S, Gosswein S, Hahn J, Kienhofer D, et al. Menage-a-Trois: the ratio of bicarbonate to $\mathrm{CO} 2$ and the $\mathrm{pH}$ regulate the capacity of neutrophils to form NETs. Front Immunol (2016) 7:583. doi:10.3389/fimmu.2016.00583

179. Leppkes M, Maueroder C, Hirth S, Nowecki S, Gunther C, Billmeier U, et al. Externalized decondensed neutrophil chromatin occludes pancreatic ducts and drives pancreatitis. Nat Commun (2016) 7:10973. doi:10.1038/ ncomms 10973

180. Pilsczek FH, Salina D, Poon KK, Fahey C, Yipp BG, Sibley CD, et al. A novel mechanism of rapid nuclear neutrophil extracellular trap formation in response to Staphylococcus aureus. J Immunol (2010) 185(12):7413-25. doi:10.4049/jimmunol.1000675

181. Yipp BG, Kubes P. NETosis: how vital is it? Blood (2013) 122(16):2784-94. doi:10.1182/blood-2013-04-457671

182. Kenny EF, Herzig A, Kruger R, Muth A, Mondal S, Thompson PR, et al. Diverse stimuli engage different neutrophil extracellular trap pathways. Elife (2017) 6:e24437. doi:10.7554/eLife.24437

183. Hakkim A, Fuchs TA, Martinez NE, Hess S, Prinz H, Zychlinsky A, et al. Activation of the Raf-MEK-ERK pathway is required for neutrophil extracellular trap formation. Nat Chem Biol (2011) 7(2):75-7. doi:10.1038/ nchembio. 496

184. Keshari RS, Verma A, Barthwal MK, Dikshit M. Reactive oxygen speciesinduced activation of ERK and p38 MAPK mediates PMA-induced NETs release from human neutrophils. J Cell Biochem (2013) 114(3):532-40. doi: $10.1002 /$ jcb. 24391

185. Douda DN, Khan MA, Grasemann H, Palaniyar N. SK3 channel and mitochondrial ROS mediate NADPH oxidase-independent NETosis induced by calcium influx. Proc Natl Acad Sci U S A (2015) 112(9):2817-22. doi:10.1073/ pnas. 1414055112

186. Khan MA, Farahvash A, Douda DN, Licht JC, Grasemann H, Sweezey N, et al. JNK activation turns on LPS- and Gram-negative bacteria-induced NADPH oxidase-dependent suicidal NETosis. Sci Rep (2017) 7(1):3409. doi:10.1038/s41598-017-03257-z 
187. Cote O, Clark ME, Viel L, Labbe G, Seah SY, Khan MA, et al. Secretoglobin $1 \mathrm{~A} 1$ and $1 \mathrm{~A} 1 \mathrm{~A}$ differentially regulate neutrophil reactive oxygen species production, phagocytosis and extracellular trap formation. PLoS One (2014) 9(4):e96217. doi:10.1371/journal.pone.0096217

188. Yuen J, Pluthero FG, Douda DN, Riedl M, Cherry A, Ulanova M, et al. NETosing neutrophils activate complement both on their own NETs and bacteria via alternative and non-alternative pathways. Front Immunol (2016) 7:137. doi:10.3389/fimmu.2016.00137

189. Mor-VakninN,PunturieriA,Sitwala K, FaulknerN,LegendreM,KhodadoustMS, et al. The DEK nuclear autoantigen is a secreted chemotactic factor. Mol Cell Biol (2006) 26(24):9484-96. doi:10.1128/MCB.01030-06

190. Bianchi ME, Manfredi AA. High-mobility group box 1 (HMGB1) protein at the crossroads between innate and adaptive immunity. Immunol Rev (2007) 220:35-46. doi:10.1111/j.1600-065X.2007.00574.x

191. Castiglioni A, Canti V, Rovere-Querini P, Manfredi AA. High-mobility group box 1 (HMGB1) as a master regulator of innate immunity. Cell Tissue Res (2011) 343(1):189-99. doi:10.1007/s00441-010-1033-1

192. Bianchi ME, Manfredi AA. How macrophages ring the inflammation alarm. Proc Natl Acad Sci U S A (2014) 111(8):2866-7. doi:10.1073/pnas. 1324285111

193. Scaffidi P, Misteli T, Bianchi ME. Release of chromatin protein HMGB1 by necrotic cells triggers inflammation. Nature (2002) 418(6894):191-5. doi:10.1038/nature00858

194. Rovere-Querini P, Capobianco A, Scaffidi P, Valentinis B, Catalanotti F, Giazzon M, et al. HMGB1 is an endogenous immune adjuvant released by necrotic cells. EMBO Rep (2004) 5:825-30. doi:10.1038/sj.embor.7400205

195. Bianchi ME, Manfredi AA. Immunology. Dangers in and out. Science (2009) 323(5922):1683-4. doi:10.1126/science.1172794

196. Tang D, Kang R, Livesey KM, Cheh CW, Farkas A, Loughran P, et al. Endogenous HMGB1 regulates autophagy. J Cell Biol (2010) 190(5):881-92. doi:10.1083/jcb.200911078

197. Campana L, Santarella F, Esposito A, Maugeri N, Rigamonti E, Monno A, et al. Leukocyte HMGB1 is required for vessel remodeling in regenerating muscles. J Immunol (2014) 192(11):5257-64. doi:10.4049/jimmunol.1300938

198. Cottone L, Capobianco A, Gualteroni C, Perrotta C, Bianchi ME, RovereQuerini P, et al. 5-Fluorouracil causes leukocytes attraction in the peritoneal cavity by activating autophagy and HMGB1 release in colon carcinoma cells. Int J Cancer (2015) 136(6):1381-9. doi:10.1002/ijc.29125
199. Cottone L, Capobianco A, Gualteroni C, Monno A, Raccagni I, Valtorta S, et al. Leukocytes recruited by tumor-derived HMGB1 sustain peritoneal carcinomatosis. Oncoimmunology (2016) 5(5):e1122860. doi:10.1080/2162 402X.2015.1122860

200. Banerjee S, de Freitas A, Friggeri A, Zmijewski JW, Liu G, Abraham E. Intracellular HMGB1 negatively regulates efferocytosis. J Immunol (2011) 187(9):4686-94. doi:10.4049/jimmunol.1101500

201. Banerjee S, Friggeri A, Liu G, Abraham E. The C-terminal acidic tail is responsible for the inhibitory effects of HMGB1 on efferocytosis. J Leukoc Biol (2010) 88(5):973-9. doi:10.1189/jlb.0510262

202. Friggeri A, Yang Y, Banerjee S, Park YJ, Liu G, Abraham E. HMGB1 inhibits macrophage activity in efferocytosis through binding to the alphavbeta3integrin. Am J Physiol Cell Physiol (2010) 299(6):C1267-76. doi:10.1152/ ajpcell.00152.2010

203. Schaper F, de Leeuw K, Horst G, Bootsma H, Limburg PC, Heeringa P, et al. High mobility group box 1 skews macrophage polarization and negatively influences phagocytosis of apoptotic cells. Rheumatology (Oxford) (2016) 55(12):2260-70. doi:10.1093/rheumatology/kew324

204. Han CZ, Ravichandran KS. Metabolic connections during apoptotic cell engulfment. Cell (2011) 147(7):1442-5. doi:10.1016/j.cell.2011.12.006

205. Olenchock BA, Rathmell JC, Vander Heiden MG. Biochemical underpinnings of immune cell metabolic phenotypes. Immunity (2017) 46(5):703-13. doi:10.1016/j.immuni.2017.04.013

206. Park D, Han CZ, Elliott MR, Kinchen JM, Trampont PC, Das S, et al. Continued clearance of apoptotic cells critically depends on the phagocyte Ucp2 protein. Nature (2011) 477(7363):220-4. doi:10.1038/nature10340

Conflict of Interest Statement: The authors declare that the research was conducted in the absence of any commercial or financial relationships that could be construed as a potential conflict of interest.

Copyright (c) 2018 Manfredi, Ramirez, Rovere-Querini and Maugeri. This is an open-access article distributed under the terms of the Creative Commons Attribution License (CC BY). The use, distribution or reproduction in other forums is permitted, provided the original author(s) and the copyright owner are credited and that the original publication in this journal is cited, in accordance with accepted academic practice. No use, distribution or reproduction is permitted which does not comply with these terms. 